\title{
Systemic Immunity against Soil Borne Phytophthora and Control of Ink Disease of Chestnut by Foliar Spray of Potassium Phosphonate
}

\author{
E. Gouveia, V. Coelho, F. Fonseca, L. Nunes and L. Monteiro \\ IPB, University of Applied Sciences of Bragança \\ CIMO, Centro de Investigação de Montanha \\ Campus Santa Apolónia, 5301- 037 Bragança \\ Portugal
}

Keywords: chestnut ink disease, phosphite, phosphonates, integrated control measures, biochemical fungicides

\begin{abstract}
Chestnut ink disease represents a great risk for chestnut (Castanea sativa Mill.) in all regions of chestnut production of Europe and North America. Induced by soil borne oomycetes, Phytophthora cinnamomi and $P$. cambivora, both parasites infect the root system and cause root and collar rot resulting in dieback, decline and finally, the death of infected trees. There are no single control measures for root rot pathogens and control with systemic and selective oomycetes biochemical substances can be important as part of the integrated disease management of these soil borne parasites. In this work we studied the effect of potassium phosphonate to protect roots from $P$. cinnamomi. Chestnut seedlings were planted in potting mix previously inoculated with $P$. cinnamomi (Pr 120). One group of five pots, with three seedlings each were submitted to potassium phosphonate foliar spraying $\left(3 \mathrm{ml} \mathrm{L}^{-1}\right.$ Atlante $\left.{ }^{\mathrm{s}}\right)$ and another group of five pots were water foliar sprayed. Seedlings had been grown in a nursery for 120 days. At the end of the experiment, visual symptoms of the crown and root system were assessed. Parameters related with roots: root length, root rot length, root number, root rot number, crown diameter, height and biomass were evaluated. Statistic significant differences between treatments were obtained in all root studied variables. Potassium phosphonate by foliar spraying prevented $P$. cinnamomi infections of roots of chestnut and can be a key factor in the management of ink disease of chestnut.
\end{abstract}

\section{INTRODUCTION}

Chestnut ink disease represents a great and continuing threat to chestnut (Castanea sativa Mill.) in all regions of chestnut production. Induced by soil borne oomycetes, Phytophthora cinnamomi and P. cambivora (Tucker, 1931; Pimentel, 1947; Urquijo, 1947; Crandall, 1950; Grente, 1961), both parasites infect the root system and cause root and crown rot. Symptoms can be apoplectic and the tree rapidly dies or results in dieback, long-lasting decline and in the end, death of the infected trees occurs. Dead roots reduce water and mineral uptake which stresses the tree over several years before symptoms of dieback and rearing of the crown are visible above ground. Symptoms of the disease may be non-specific and diverse which hamper diagnoses and management. Despite the presence of the pathogens and their devastating epidemics in Europe since the second half of the $19^{\text {th }}$ century (Zentmyer, 1980) and even though many and varied approaches to control the disease were studied, there are no simple solutions for these root rot pathogens. Chemical control with systemic and selective oomycetes products can be an important factor and part of the integrated management of soil borne Phytophthora. Phosphonates are salts or esters of phosphonic acid (Guest and Grant, 1991) but in recent literature, when these products were applied for protection of plant diseases the term phosphite is also frequent. Daniel et al. (2005) and Daniel and Guest (2006) stated that following phosphonate treatment challenged cells in normally susceptible plant species undergo rapid cytological changes that include nuclear migration and hypersensitive cell death, activate defence-related biosynthetic pathways and accumulate higher levels of phytoalexins and deposit of physical barriers around challenged cells. Activities of 
enzymes involved in defence mechanisms are also elevated in normally susceptible Eucalyptus marginata seedlings treated with phosphonate that includes phenylalanine ammonia lyase (PAL), 4- coumarate coenzyme-A ligase (4-CL), cinnamyl alcohol dehydrogenase (CAD), and the synthesis of phenolic compounds (Jakson et al., 2000).

Phosphonates are officially approved to control Sudden Oak Death associated with P. ramorum (Garbelotto and Douglas, 2009) in California and "Jarrah" dieback associated to P. cinnamomi (Jakson et al., 2000) in Australia and some reported experiments reveal phosphonate efficacy in many others Phytophthora host interactions (Wilkinson et al., 2001). A range of responses to phosphonate application are also reported depending on the plant species and time of application (Wilkinson et al., 2001; Navarro et al., 2006). The present work provides data on biological activity of potassium phosphanate $\left(\mathrm{H}_{2} \mathrm{PO}_{3}{ }^{-}\right)$, the anionic form of phosphonic acid, against $P$. cinnamomi in chestnut seedlings and its efficacy in controlling ink disease by preventive foliar application. To take into account some potentially negative effects of phosphonate, direct toxicity against beneficial soil micro-organisms were also evaluated in vitro to provide useful information to aid in the implementation of a viable management treatment for ink disease of chestnut.

\section{METHODS}

\section{Nursery Plant Experiments}

Experiments where performed at an IPB/ESA nursery and carried out on pot mix previously inoculated with $P$. cinnamomi (Pr 120). Chestnut seedlings similar in size and vigour were selected, rinsed free of original substrate and immediately planted in the uniformly $P$. cinnamomi infested potting mix. Seedlings were sprayed with distilled water or potassium phosphonate (Atlante ${ }^{\circledR}-30 \% \mathrm{P}_{2} \mathrm{O}_{5}, 20 \% \mathrm{~K}_{2} \mathrm{O}$ ). The seedlings were sprayed to run-off using a sprayer. Atlante ${ }^{\circledR}$ was applied as a formulated product at the recommended field dosage application $\left(3 \mathrm{ml} \mathrm{L}^{-1}\right)$. The foliage was allowed to dry naturally for $12 \mathrm{~h}$ before the watering programme was re-established. Pots were also flooded weekly. Fifteen seedlings were used per treatment with three seedlings per pot of $15 \mathrm{~L}$ capacity arranged randomly. After 120 days, chestnut seedlings were removed and the roots rinsed free of soil particles. Root rot length, total root length, root weight, visual above-ground symptoms and biomass of root and stem were evaluated. Additionally, segments from necrotic roots and healthy ones and also their respective potting mix were plated on PVPH medium for re-isolation of the inoculated P. cinnamomi. Statistical analysis was conducted using the student t-test for means comparison on untransformed data to analyse the differences between phosphonate and water application. The significance level of the test ( $p$-value) was set at 0,05 . The assumptions on normality and heterocedasticity of residual values were checked by Shapiro-Wilk test and Levene, respectively (software SPSS $16.0^{\mathbb{R}}$ ).

\section{In Vitro Phosphonate Toxicity}

Tests in vitro were performed to provide some information related to phosphonate toxicity to $P$. cinnamomi and $P$. cambivora isolates, Cryphonectria parasitica, a virulent fungus that causes chestnut blight, and Pisolithus tintorious, a basidyomicete and mycorrhizal chestnut root fungus. Five-mm plugs of each isolate from an active culture grown on PDA (Difco) were transferred to three replicates PDA plates containing 0, 5, $20,50 \mu \mathrm{g} \mathrm{ml}^{-1}$ of potassium phosphonate, then the plates were incubated at $22-24^{\circ} \mathrm{C}$ for 5 days. Colony diameters were measured and the average colony area was determined for each concentration and expressed as the percentage of the no-phosphonate control. Percentage values were plotted as probit versus $\log _{10}$ of the phosphonate concentration and analyzed by linear regression. The regression equation was used to estimate the $\mathrm{EC}_{50}$ (concentration inhibiting mycelia growth by $50 \%$ ) for each isolate. 


\section{RESULTS}

\section{Nursery Plant Experiment}

At the end of the experiment differences in general conditions and above ground symptoms of chestnut seedlings were obvious. All chestnut seedlings that grew in $P$. cinnamomi infested potting mix and treated with phosphonate were apparently healthy whereas the water application seedlings manifested visible and characteristic ink disease symptoms. When chestnut seedlings were removed from the pots, differences in root rot symptoms and root development were also easily observable and marked.

Statistical analyses by the t-test and means comparison revealed significant differences between treated and untreated chestnut seedlings for all root studied parameters, namely, root length, healthy root length, root rot length, root number, root rot number, root weight and biomass of roots (Table 1).

\section{In Vitro Phosphite Toxicity}

$\mathrm{EC}_{50}$ values for $P$. cinnamomi were generally near or below $1 \mu \mathrm{g} \mathrm{ml}^{-1}$ but the isolate $\operatorname{Pr} 125$ has shown a higher value which revealed the existence of reduced sensitivity in some $P$. cinnamomi isolates. $\mathrm{EC}_{50}$ values for $P$. cambivora averaged $16,2 \mu \mathrm{g}$ $\mathrm{ml}^{-1}$ ranged from 9,92 to $22,44 \mu \mathrm{g} \mathrm{ml}^{-1}$ (Table 2). The basidiomycete Pysolithus tintorius, a mycorrhizal fungus of chestnut seedlings, evidenced an intermediate value. Higher values of $\mathrm{EC}_{50}$ were obtained for the tested ascomycete Cryphonectria parasitica virulent strain associated with chestnut blight.

\section{DISCUSSION AND CONCLUSIONS}

Phosphite and phosphonate mode of action in plant resistance is still not completely elucidated but appears to be a combination of direct inhibition of pathogen growth and stimulation of plant defence responses, possibly via an increase in the production of pathogen derived elicitors or a decrease in the production of pathogen derived suppressors of the defence response as stated by some authors (Jackson et al., 2000; Guest and Grant, 1991; Hardham, 2005).

In this experiment all parameters related with roots were significantly different in chestnut seedlings sprayed with phosphonate. Healthy status of the root system after four months of phosphonate treatment suggested a defence response in the pre-infection stages similar to those observed in an incompatible interaction.

Potassium phosphonate by foliar application obviously did not remove $P$. cinnamomi from the soil and the pathogen was always in contact with the roots as was confirmed by isolation from the potting mix and root tissues on PVPH medium. Global control strategies of soil borne Phytophthora inevitably will have to include other sanitary measures related to the hygiene and sanitation of vegetative material in nurseries to avoid the introduction and spread of pathogens in the field and to minimize environmental determinants.

Higher in vivo activity of potassium phosphonate than observed in vitro makes $\mathrm{EC}_{50}$ a weak tool for predicting the final effect of phosphonate on beneficial or pathogenic microbes. Microbe-plant mycorrhizal interaction must be evaluated because plants may become vulnerable by the possible disruption on their symbiotic microbes. Further studies are also needed to determine potential negative effects such as the induced deficiency of phosphorus reported in the literature by some authors (McDonald et al., 2001; Landchoot and Cook, 2005) as well as optimal rates of active ingredient and ideal time of application.

\section{Literature Cited}

Crandall, S. 1950. The distribuition and significance of the chestnut root rot Phytophthoras, P. cinnamomi and P. cambivora. Plant Disease Reporter 34(6):194196.

Daniel, R. and Guest, D. 2006. Defence responses induced by potassium phosphonate in 
Phytophthora palmivora-challenged Arabidopsis thaliana. Physiological and Molecular Plant Pathology 67:194-201.

Daniel, R., Wilson, B. and Cahill, D. 2005. The effect of potassium phosphonate on the response of Xanthorrhoea australis to infection by Phytophthora cinnamomi. Australasian Plant Pathology 34:541-548.

Garbelotto, M. and Douglas, J. 2009. Phosphonate controls Sudden Oak Death pathogen for up to years. California Agriculture 63(1):10-17.

Grente, J. 1961. La maladie de l'encre du chataignier. I-Étiologie et biologie. Ann. Epiphyties 12:6-24.

Guest, D. and Grant, B. 1991. The complex action of phosphonates as antifungal agents. Biological Review 66:157-87.

Hardham, A. 2005. Pathogen profile. Phytophthora cinnamomi. Molecular Plant Pathology 6:596-604.

Jackson, T., Burgess, T., Colquhoun, I. and Hardy, G. 2000. Action of the fungicide phosphite on Eucalyptus marginata inoculated with Phytophthora cinnamomi. Plant Pathology 49:147-154.

Landchoot, P. and Cook, J. 2005. Sorting out the phosphonate products. p.73-77. In: Golf Course Management. November.

McDonald, A., Grant, B. and Plaxton, W. 2001. Phosphite (phosphorus acid): its relevance in the environment and agriculture and influence on plant phosphate starvation response. Journal Plant Nutrition 24:1505-1519.

Navarro, C., Terán, A. and Sánchez, M. 2006. Acción preventiva y curativa del fosfonato en el control de Phytophthora cinnamomi Rands en encina y alcornoque. Boletín de Sanidad Vegetal Plagas 32:685-694.

Pimentel, A. 1947. A Phytophthora cinnamomi Rands, um outro agente, extremamente virulento, da "doença da tinta" do castanheiro. Separata da Agronomia Lusitana, Vol IX, Tomo III.

Tucker, C. 1931. Taxonomy of the genus Phytophthora de Barry. Missouri Agri. Exp. Sta. Res. Bull. 153. (Cit: Grente, 1961).

Urquijo, L. 1947. Revisión taxonómica de los hongos productores de la enfermedad del castaño llamada de la "tinta". Ministerio de Agricultura, Instituto Nacional de Investigaciones Agronómicas. Estacion de Fitopatología Agrícola de la Coruña.Trabajos (serie Fitopatogia), 188. Madrid.

Wilkinson, C., Holmes, J., Tynan, K., Colquhoun, I., Mccomb, J., Hardy, G. and Dell, B. 2001. Ability of phosphite applied in a glasshouse trial to control Phytophthora cinnamomi in five plant species native to Western Australia. Australasian Plant Pathology 30:343-351.

Zentmyer, G.A. 1980. Phytophthora cinnamomi and diseases it causes. Monograph $\mathrm{n}^{\circ} 10$. The American Phytopatologycal Society. St Paul, Minnesota, USA. 
$\underline{\text { Tables }}$

Table 1. Statistical summary of root parameters and above ground parameters of chestnut seedlings that grew in potting mix infested with Phytophthora cinnamomi with preventive foliar phosphonate or water spraying.

\begin{tabular}{lcc}
\hline Parameters & Treatment & Mean \pm std. error \\
\hline \multirow{2}{*}{ Root length $(\mathrm{cm})$} & Phosphite sprayed & $1027,04 \pm 120,29 \mathrm{a}$ \\
& Water sprayed & $660,40 \pm 85,77 \mathrm{~b}$ \\
Healthy root length $(\mathrm{cm})$ & Phosphite sprayed & $991,57 \pm 124,06 \mathrm{a}$ \\
& Water sprayed & $31,88 \pm 31,88 \mathrm{~b}$ \\
Root rot length $(\mathrm{cm})$ & Phosphite sprayed & $31,54 \pm 12,71 \mathrm{a}$ \\
& Water sprayed & $628,52 \pm 66,79 \mathrm{~b}$ \\
Root number $\left(\mathrm{n}^{\circ}\right)$ & Phosphite sprayed & $49,57 \pm 4,54 \mathrm{a}$ \\
& Water sprayed & $36,62 \pm 2,58 \mathrm{~b}$ \\
Root rot number $\left(\mathrm{n}^{\circ}\right)$ & Phosphite sprayed & $3,07 \pm 1,27 \mathrm{a}$ \\
& Water sprayed & $36,23 \pm 2,70 \mathrm{~b}$ \\
Root dry weight $(\mathrm{g})$ & Phosphite sprayed & $2,52 \pm 0,44 \mathrm{a}$ \\
& Water sprayed & $1,05 \pm 0,10 \mathrm{~b}$ \\
Stem and foliar dry weight $(\mathrm{g})$ & Phosphite sprayed & $4,06 \pm 0,49 \mathrm{a}$ \\
& Water sprayed & $4,66 \pm 0,45 \mathrm{a}$ \\
Annual grown $(\mathrm{cm})$ & Phosphite sprayed & $9,68 \pm 1,11 \mathrm{a}$ \\
& Water sprayed & $11,04 \pm 1,35 \mathrm{a}$ \\
Crown diameter $(\mathrm{cm})$ & Phosphite sprayed & $0,63 \pm 0,03 \mathrm{a}$ \\
& Water sprayed & $0,53 \pm 0,04 \mathrm{~b}$ \\
\hline
\end{tabular}

Means in each parameter followed by the same letter do not differ significantly at $\mathrm{P} \leq 0,05$ by t-test

Table 2. $\mathrm{EC}_{50}\left(\mu \mathrm{g} \mathrm{ml}^{-1}\right.$ of potassium phosphonate - Atlante $\left.{ }^{\circledR}\right)$ of Phytophthora cinnamomi, P. cambivora, Pisolithus tinctorius and Cryphonectria parasitica.

\begin{tabular}{lcccccccc}
\hline \multirow{2}{*}{ Species } & \multicolumn{4}{c}{ P. cinnamomi } & \multicolumn{2}{c}{ P. cambivora } & \multirow{2}{*}{$\begin{array}{c}\text { Pisolithus } \\
\text { tinctorius }\end{array}$} & $\begin{array}{c}\text { Cryphonectria } \\
\text { parasitica }\end{array}$ \\
\cline { 2 - 7 } & $\operatorname{Pr} 120$ & 810 & 804 & $\operatorname{Pr} 125$ & $\operatorname{Ar} 102$ & $\operatorname{Pr} 135$ & \\
\hline $\mathrm{EC}_{50} *$ & 1,34 & 0,64 & 0,97 & 31,56 & 9,92 & 22,44 & 14,10 & 44,39 \\
\hline
\end{tabular}

*Concentration of potassium phosphonate $\left(\right.$ Atlante $^{(B)}$ ) causing $50 \%$ of mycelial growth inhibition compared to growth on no amended PDA 
